\title{
Impacts of Forest Related Large-Scale Land Acquisitions in the Indian Ocean World
}

\author{
Alexandre Corriveau-Bourque \\ Ingrid L. Nelson \\ Matthew Pritchard \\ J. David Stanfield \\ Jon D. Unruh
}

\begin{abstract}
With the 'global land grab' now a primary ongoing process in the developing world, greater attention to region-specific analyses provides critical insights for effective policy responses. The Indian Ocean world has the greatest regional concentration of large-scale land acquisitions (LSLAs) globally, and it is also where most of the investor countries reside. Yet examination of Indian Ocean specific patterns and processes of LSLAs are lacking. One of the most sought after category of lands are those in forested or recently forested areas, due to their high potential natural resource and agricultural value. This review article examines the primary issues, actors, and impacts of LSLAs of forest-related lands in the broader Indian Ocean world, while assessing the opportunities for national populations of target countries as well as investors and the key social and environmental concerns requiring policy attention.
\end{abstract}

\section{Introduction}

The Indian Ocean World (IOW) is the epicentre of the process known as the 'global land grab'. Most of the world's large-scale land acquisitions (LSLAs), in terms of transactions as well as target and investor countries, are located within the region (e.g., Borras and Franco, 2010; Daniel, 2011; Smaller and Mann, 2009), (Figures 1 and 2). The size and pervasiveness of LSLAs will have a growing impact on how the region influences broad processes of globalization, food and fuel security, climate change, migration and economic relations (e.g., ABN, 2007; Campbell, 2009; Andrianirina-Ratsialonana, 2011; Cotula et al., 2011). Such acquisitions particularly target forested lands for their multiple uses and multiple investment returns. The sequential (and occasionally simultaneous) financial opportunities of timber and other forest products (e.g. from carbon currently held in woody biomass, commercial agriculture once land is deforested, commercial grazing when converted from agriculture, and woody biomass increment for carbon storage when forests regrow ${ }^{1}$ ) generate greater income than acquiring purely agricultural or grazing land. At the same time, the preservation of large and biodiverse forests is critical for mitigating global warming and supporting biodiversity and its related contributions to medical advancement (among other opportunities). Forests are also particularly contentious domains of indigenous land rights.

\footnotetext{
${ }^{1}$ Carbon held in standing stocks of woody biomass, and carbon added to a landscape through regrowing forest, are two separate investment opportunities in the domain of carbon credits and offsets.
} 


\section{$>>$ Insert figure $1<<$ \\ $>>$ Insert figure $2<<$}

Most analyses of LSLAs do not disaggregate by the category of land being acquired, and as a result, category-specific impacts are not understood. Moving beyond general descriptions of LSLAs into more penetrating analyses requires a focus on their impacts as they pertain to specific categories of land resources in important regions of the world. This article examines large-scale land acquisitions (LSLAs) in forest-related areas of the IOW. The acquisition of forested lands in the region by actors and interests from elsewhere in the IOW and beyond, has a significant regional and global impact, a deep attachment to historical processes, and a direct influence on environmental change and globalization. Analysis of these acquisitions is imperative, given their increasing role in shaping political-economic relationships between countries, and their repercussions on local livelihoods, migration and economies.

\section{Drivers of LSLAs}

The increasing globalization of trade and associated acquisition of enormous tracts of land has become a major driver of forest landscape transformation in the IOW as a result of a growing demand for forest products (e.g., timber, pulp and paper), food and fuel crops (e.g., oil palm, soybeans, sugarcane) and grazing land. The outcomes of this land acquisition process are to date ambiguous. On one hand, they can generate new opportunities for developing countries of the IOW to enhance their capital base and increase foreign exchange earnings from the production of primary goods. On the other hand, globalizing trade and LSLAs can lead to the redistribution and concentration of rights over land and other productive resources, leading to significantly negative repercussions, including large-scale dislocation, extreme food insecurity, poverty and armed conflict.

Rarely are LSLAs focused solely on land itself, but rather a characteristic of the land, such as specific resources and locations, even if such lands are acquired for the purpose of speculation or 'banking land'. Some land resources are more easily exploited than others and so require less in the way of acquisition or time, and therefore can involve different kinds of rights over land than would longer-term acquisitions. For example timber extraction is more short-term and arguably easier to accomplish than the planting of oil palm or other tree plantations, which require significant time for revenue generation.

A number of acquisition types can be traced to the colonial era or before in any one country. Other large-scale land deals were common after the colonial era but before the present surge in LSLAs. Mineral and timber exploitation are good examples, having been present in a variety of forms beginning with the colonial era in various countries up to the present. However the kind of mineral resources being exploited have now expanded substantially, as have the number of areas being mined and their spatial extent (Karsenty, 2010). Other acquisition types are more recent, and have emerged due to a combination of technological advancement, socio-political trends, and prices. Biofuels in particular have come about recently with ways to more easily and economically convert forms of agricultural produce into fuels and gain energy from such fuels, 
together with green politics, a desire to diversify fuel sources and pricing (Sulle and Nelson, 2009; Schoneveld, 2010; WWF, 2010).

Acquiring large tracts of land for food supply in the IOW deserves particular mention. A primary reason for the current interest in the IOW, is the desire for increased food security by those countries and interests elsewhere in the IOW initiating the acquisitions. Of the estimated 115 million acres of farmland that are leased globally, the majority are in east Africa (Figure 3). As climate change begins to threaten agricultural calendars and hence productivity in many regions of the IOW and beyond, acquiring farmland has emerged as a priority for wealthier countries such as China, India, Qatar, Jordan, Kuwait, Saudi Arabia, South Africa and Malaysia. These countries lease or purchase lands primarily in eastern African countries, but also in Cambodia, Laos, the Philippines, Indonesia, Pakistan and Yemen. The countries doing the leasing or purchasing are interested in securing future food production for their domestic populations. Attempts to review, analyze and promote a variety of international standards, certifications, codes of conduct and policies regarding LSLAs for food production have proven to be significantly challenging, disparate, and pose difficulties in their enforcement (de Schutter, 2009; Borras and Franco, 2010a; Hallam, 2011). Certainly both investors and local populations are concerned about the fate of the food produced on such lands if widespread food shortage occurs in the source country. Questions of equity, sustainability, and viability of contracts are important in such scenarios (Deninger et al., 2011). While acquiring forest-related land and clearing it for agriculture by foreign interests is not new, the acquisition of land for national food security purposes for the investor country in a different part of the IOW (food importing countries have been amongst the biggest players) has emerged as a relatively new phenomenon related to recent uncertainties and scarcity in the global food supply, highlighted by the record-setting global food prices in, 2008 and again in 2011 (Smaller and Mann, 2009). Thus acquisitions are to a large degree driven by concerns over what climate change, growing populations, increasing affluence, and price uncertainty will mean for investor countries wishing to attend to their own population's needs and aspirations (ABN, 2007; Smaller and Mann, 2009; Murphy et al., 2011).

\section{$>$ Insert figure $3<<$}

In addition the relationships between types of investments are largely unexplored. The LSLAs of areas for biofuel production can shift land availability for food production, which can threaten food security and catalyze desires to acquire still more land for food production. Still other forms of acquisition have developed as political and advocacy movements have matured, including those acting on behalf of indigenous groups, smallholder communities, and a broad range of environmental issues (Venter et al., 2009; Andrianirina-Ratsialonana et al., 2011; Hanlon, 2011 part 1). While the designation of large areas for hunting, national parks and reserves occurred in the colonial era, acquiring land for the purpose of conservation, biodiversity and habitat preservation or other forms of environmental protection are becoming increasingly common and occur in an assortment of approaches. These interact with local populations in a variety of ways, particularly with regard to how local populations are able to continue to use, or not, specific resources (Ramos and Bonilla, 2009; Agarwal, 2010; Mpoyi, 2010; Molnar et.al., 2011). 
Other forms of acquisition are not presently large-scale or widespread but are very likely to grow in the future. Carbon forests and the different ways that countries, investors and local communities may be able to derive revenue from various arrangements are currently gaining considerable attention as the potential for revenue becomes more widely known, and the policy, legal, and financial approaches become solidified (Instituto Sociambiental and Forest trends, 2010; Schoneveld, 2010; Corbera et al., 2011). Still other types of acquisitions have been common in the past, and occur in the same way currently, but are notable primarily for the enormity of areas now affected. Of particular concern is the conversion of forest land for grazing and the associated livestock production, and the vast areas now in this land use that were once forest (ABN, 2007; WWF, 2009; Molnar, et.al., 2011). But also important is the conversion of forests to tree plantations and clear cutting for timber (Forster and Stanfield, 1993; Filippini, 2009; Venter et al., 2009; Lambin and Meyfroidt, 2011).

\section{Methods}

This paper considers the LSLA of areas both adjacent to forests as well as within forests in the IOW. Areas adjacent to forests in a great many cases were once forest themselves, but once converted to agricultural or pastoral areas are then categorized differently, such that there is considerable ambiguity regarding what is 'forest land'.

The present work has involved an exhaustive literature review and the creation of a bibliographic database which details information about specific forest-related acquisitions, along with general trends in specific countries of the IOW (Figure 4). Appendix I provides the categories of acquisition types treated in the bibliographic database. The different types of acquisitions considered in this paper vary considerably in how frequently they occur; the land areas involved; and the histories of how they came about, operate, and treat local governments and local populations.

\section{$>>$ Insert figure $4<<$}

\section{Overview}

\section{Impacts of Forest-Related LSLAs in the IOW}

The direct and broader impacts of LSLAs are often not immediately clear to observers. The existing body of literature rarely accurately assesses the impacts of LSLAs on people living in the spaces appropriated, because very little ecological or socio-economic information is gathered on the ground before such acquisitions take place. While some projects carry out Environmental Impact Assessments (EIAs) or Environmental and Social Impact Assessments (ESIAs), the overwhelming majority do not, and both assessment types are prone to corruption and powerimbalances (Andrianirina-Ratsialonana et. al, 2011). Field data concerning the effects of LSLAs after the fact are also rare. At this juncture, the primary sources of evaluations of observable impacts come from specifically contracted field studies, information from those who have been dislocated or otherwise affected, and from activist organizations and (local/international) news media. 
The impacts of LSLAs can be direct, indirect or a mixture of both. A LSLA cleared of forest for biofuel production for example, may formally relocate an affected population to prepared sites, compensate others, and displace others in a scattered way well beyond the project site, all simultaneously. This makes any resulting impacts difficult to effectively assess.

Our team reviewed the literature and coded possible observed impacts according to the following list:

- Production of wood, fibre, palm oil, rubber;

- Production/destruction of other forest products;

- Sustainable use of forests, bio-diversity;

- Former users of forests assured/deprived of access to forests;

- Former users of bordering non-forested lands moved into forests;

- Looting of forests;

- Changes in welfare of users of the forests;

- Employment increased/decreased in acquisition area;

- Community cohesion/division affected (can be across different family status, gender, age, traditional healers etc.);

- New conflicts between urban populations (resource demand) and communities (year-round residents);

- Conflicts, resistance to acquisitions;

- Community and public sector capacities for monitoring acquisitions and resolving problems as they arise (improved/weakened);

- Rising land values.

All of these impacts were reported in the literature. The most commonly reported included, the increased production of industrial forest products (palm oil, wood chips, etc.), destruction of other forest products, the generation of new divisions within communities along gender and socio-economic lines, and former users of forests and forest adjacent areas being deprived of access.

\section{Impacts}

The impacts of LSLAs in forestry settings are first and foremost highly context-dependent. The particular assemblage ${ }^{2}$ of host country state laws, the implementation of these laws, the roles of national elites, the physical environment, cultural practices and the economic realities of local populations, all influence the potential impacts of LSLAs. Apart from context, the most important factors that affect impacts are the intended land-use objectives of acquisitions and the expected temporal footprint of the investors. For instance, timber extraction in a context of minimal institutional oversight can be implemented quickly and ruthlessly, resulting in the rapid clear-cutting of forests (as observed in Indonesia and Malaysia: Casson, 2003; Lambin and Meyfroidt, 2011), and a disregard for local land rights (Karsenty et al., 2008a). However, if

${ }^{2}$ See Li (2007) for an explanation of how such assemblages work in forest contexts. 
timber extraction is done in a context where host nations have both the capacity (and desire) to establish oversight mechanisms (whereby investors must comply with product certification regimes), such forestry can be done scientifically and sustainably.

\section{Relationships between impacts: environment and governance}

One important finding from the current work is that the relationship between impacts can be important. For example, the growing demand for biofuels and palm-oil based products has been driving deforestation and biodiversity loss in Indonesia and Malaysia (Casson, 2003; Venter et al., 2009). In the Indonesian case investors often abuse the government's incentives to develop the palm oil industry, in that they clear-cut parcels of forest allocated for palm plantations in order to derive income from the harvested timber, but then fail to replant with palm oil (Casson, 2003; Venter et al., 2009). Between 1990 and 2005, 55 to 60 percent of oil palm expansion in Indonesia and Malaysia occurred through such clearing of forests (Schoneveld et al., 2010). ${ }^{3}$ At the same time the governments in each of these countries have recently taken measures (policy review, moratoriums on expansions, forest-cover maintenance requirements, requiring environmental impact assessments, and the creation of ecological zoning laws) to stem the destruction of forests (Karsenty et al., 2008b; Schoneveld et al., 2010). However, poor enforcement capacity for these measures undermines their potential environmental benefits (Karsenty et al., 2008b; Schoneveld et al., 2010). Thus, while the impact on the environment is straightforward--deforestation, biodiversity loss, soil degradation--there is also an indirect weakening of state institutions and processes designed to protect the environment, and in particular forests. Weak state capacity has also played a role in Cambodia, where the destruction of nearly thirty percent of the country's forest cover within a span of five years has been attributed to the capture of the country's forestry resources by government elites who are able to exploit them with little regulation (Hughes, 2008). In Madagascar, the proposed lease of nearly half the country's arable land to foreign investors led to a breakdown in the enforcement of forestry protections, resulting in rampant poaching, illegal logging of the country's fragile forests and eventually caused the collapse of the government (Williams, 2009). ${ }^{4}$ In other cases local communities respond to the threat of dislocation by cutting forests as a strategic tactic to both dissuade acquisition of their lands for forest-related purposes, and increase the strength of customary tenure claims in conditions of low tenure security (Angelsen, 2007; Unruh et al, 2005).

At the same time, the recent development of carbon credit arrangements and the subsequent drive towards reforestation of 'degraded' lands has given environmental and biodiversity advocates new tools with which they can offer governments, forest-dependent communities, and investors (Cerbu et al., 2011), although the opportunity costs of preservation still struggle to

\footnotetext{
3 According to Venter et al. (2009), the expansion of palm oil plantations in Kalimantan, Indonesia will have a particularly devastating impact on the Borneo pygmy elephant and the Bornean Orangutan, whose habitats will be reduced by thirty-one percent and 5.5 percent respectively.

4 Williams (2009) suggests that the new government is actively encouraging the quasi-illicit ebony and rosewood trade due to their taxation of exports.
} 
match those of forest exploitation (Venter et al., 2009). In many of these contexts, mono-crop forests are planted by private companies, state reforestation schemes, or through initiatives led by NGOs or communities on large tracts of land to offset carbon emissions located elsewhere (generally in the global North) (Filippini, 2009; Overbeek, 2010). Through the REDD+ framework, countries, NGOs and private companies have developed the capacity to offer financial incentives (in addition to tourism) to preserve or regrow forests in resource-rich, but capital-poor countries (Cerbu et al., 2011; Zoomers, 2011). Abuses of the principles of reforestation and carbon crediting are common. For example studies from Mozambique indicate that 'reforestation' efforts are being implemented by clearing large tracts of acquired land (gaining income from timber sales) and then planting them with mono-cropped, fast-growing, exotic but economically valuable species such as pine, oil palm, eucalyptus, and other species such as teak, with significant repercussions on local populations (Ramos and Bonilla, 2009; Filippini, 2009; Overbeek, 2010).

The weak enforcement mechanisms in countries that otherwise have pro-conservation laws often allows destructive forest-exploitation practices to flourish (Williams, 2009; Schoneveld et al., 2010; Monachon and Gonda, 2011). Even though deforestation rates can fluctuate depending on global demand for timber and other primary products, ${ }^{5}$ global deforestation on the whole and forest-land conversion is continuing at very large scales. While certain countries have even been able to reverse deforestation, Labin and Meyfroidt (2011) suggest that the decline in domestic deforestation is often matched with a transfer of exploitation to another country. This is relevant to LSLAs in the IOW, where enforced restrictions on acquisition and exploitation of forest lands in one country leads to commercial interests from that country seeking to acquire and exploit forest resources in other countries in the IOW where the legal and institutional capacity is weaker.

\section{The land category problem}

Large-scale land acquisitions in the IOW are fuelled by the widespread belief (supported by various assessments) that the region has an abundance of available 'reserve' land for food and biofuel production (Borras and Franco, 2010b; Deninger et al., 2011; Lambin and Meyfroidt, 2011). Lambin and Meyfroidt (2011) estimate that approximately 445 million hectares of such 'reserve' lands are available globally. Their criteria for suitability includes land that is not presently officially categorized as forested, is not protected, and is populated with less than 25 persons per km. In the African IOW these reserve lands are primarily concentrated in Sudan, Mozambique, Tanzania and Madagascar. A different approach is that proposed by Deninger et al. (2011), who categorize countries according to their respective land availability versus their 'yield gaps', and calculate the assumed productive potential for agriculture while comparing it to actual yields. A joint FAO-IIASA study (Fischer et al., 2002) uses remote sensing and modelling to create a global assessment of 'available' agricultural resources that are otherwise 'underused'. While 'underused' according to these projections, such areas are nonetheless organized and

\footnotetext{
${ }^{5}$ However, according to Karsenty et al. (2008b), producers often adjust to declines in global timber prices by dropping sustainable (and more costly) practices rather than reduce exploitation.
} 
administered locally, often through overlapping state and customary land tenure regimes, and are utilized by small-scale agriculturalists, pastoral peoples and/or hunter-gatherer groups for a variety of minor forest products essential to livelihoods (de Schutter, 2009; Borras and Franco, 2010b;, 2010a; Yasmi et al., 2010).

While the proponents of these projections emphasize the potential role for small-scale agriculturalists to expand agricultural productivity into forested areas, more often than not, the categories of, 'marginal', 'idle', 'unproductive', 'underused', or 'degraded' which are produced within these frameworks to describe 'reserve' lands have become central to governments and investors' strategies to justify assuming control over these spaces (Ramos and Bonilla, 2009; Borras and Franco, 2010b; Nhantumbo and Salomão, 2010; Behrman et al., 2011). This is facilitated by the fact that forest ownership and control in countries targeted for acquisition usually reside entirely or almost entirely with the state, particularly in Africa and Asia. Nearly 98 percent of Africa's forests are officially administered by governments with the remaining two percent divided between private ownership and areas designated for use or owned by local communities and 'indigenous' peoples. In Asia, governments control nearly 68 percent of forests while communities and indigenous peoples control about 26 percent (RRI, 2010-2011).

The current work has found that pre-existing local use and access rights often do not factor into investor and host government strategies involving LSLAs that promote development, economic growth or conservation. By describing desired spaces as 'underused', 'marginal' or 'idle', land becomes legally divorced from the existing customary land-use and management regimes (von Braun and Meinzen-Dick, 2009; Borras and Franco, 2010a; Schoneveld et al, 2010; Cotula and Mayers, 2011). The tension between customary, state and investor rights to resources appears to be a central feature of the debates around LSLAs. These debates are informed by a considerable history of land alienation and conflict over land rights between states and customarilyadministered communities.

Such a statutory - customary disconnect in land rights allows large-scale acquisitions into forested spaces to significantly erode local land rights. Fairly common in the literature are examples in which local needs and tenure regimes are ignored, which is unsurprising considering that investors generally appear to be targeting countries where local land tenure is already weak, and governments have demonstrated few qualms about evicting inhabitants, or not protecting customary rights in the face of encroachment by concessionaires (ABN, 2007; RRI, 2010-2011; Schoneveld et al., 2010). In Mozambique, investors were able to lease land that had been labeled 'exhausted farmland' from the state for a reforestation initiative; however, residents of the area claimed that the lands had purposefully been left fallow for regeneration within their customary system of shifting agriculture (Overbeek, 2010). The lease issued by the state, with minimal local consultation, effectively eliminated the lands from the community's production cycle, increasing the pressure for them to clear additional forest lands for agriculture. In Ethiopia, the Government reportedly leased 5000 hectares of 'sacred' forests to an India-based concessionaire to transform it into a tea and spice plantation (Afrol News, 2011). These sacred forests, in addition to their symbolic value to local communities, were also used for hunting, minor forest product gathering 
and beekeeping. The government proceeded with the transaction even after local leaders petitioned Ethiopian policy makers and politicians to support their cause.

While countries with weak land tenure protections can be targeted for attempts at acquisitions, within such countries investors target the most productive lands (especially those with access to water sources) ${ }^{6}$ and those with the best access to markets (McKenna, 2009; Overbeek, 2010). The acquisition of a country's most fertile lands (either currently or previously in forest) is frequently noted as a driver of social and political conflict (Monachon and Gonda, 2011; Zander and Dürr, 2011). The concentration of highly valued lands in the hands of a few individuals/ institutions has long been a significant driver of conflict in agrarian societies. Such concentration also increases pressure on forests, results in intensified land use practices, and/or fuels migration to urban areas due to the absence of sufficient land to maintain local needs (ABN, 2007; Ramos and Bonilla, 2009; Behrman et al, 2011; Monachon and Gonda, 2011). And in spite of innovations for the production of biofuel feedstock (primarily jatropha) or plantation-forestry schemes on 'marginal' lands, such innovations still produce more on better lands. However even lands that are labelled as 'marginal' usually have some form of land use and claim that is being impacted by these acquisitions (Overbeek, 2010; Hallam, 2011).

\section{Impacts on livelihoods}

One of the most frequently promoted 'potential benefits' of LSLAs is job creation and improved livelihoods for residents living on or around lands designated for acquisition, through technology transfers, establishing markets for crops or improved infrastructure (Cotula et al., 2011; Deninger et al., 2011). However, livelihoods are only strengthened by LSLAs under a very specific set of conditions; otherwise acquisitions can and often do have a negative impact (ABN, 2007; GRAIN, 2010; RRI, 2010-2011; Economist, 2011). In order for benefits of acquisitions to actually be shared with local communities, the communities must first be consulted, a step which only a few investors are willing to make. Even when consultations do occur, agreements are often made orally between investors and local leaders, undermining the enforceability of such agreements (Sulle and Nelson, 2009). Furthermore, as concession rights can be transferred or sold between companies, and project implementation can be subcontracted to local firms, agreements for infrastructure development, job creation, or joint management of resources may not be acknowledged by the actors who were not part of the original agreement (Karsenty et al., 2008a; Behrman et al., 2011). This is particularly problematic in environments where the state has limited capacity or will to enforce laws and contracts.

While some LSLAs may create jobs, those that are made available often require technical skills because production is usually technology intensive rather than labour intensive, meaning that companies need to bring labour in from outside the community. In a good number of cases companies even bring workers from abroad, which heightens resentment and fuels animosity (Afrol News, 2011; Economist, 2011). Even when local workers are hired, women from poor

\footnotetext{
6 For example while jatropha is able to grow on 'marginal' soils, it is far more productive in more fertile areas. Faced with this choice, investors tend to seek out the more productive of the two options (Sulle and Nelson, 2009).
} 
rural communities are often at a particular disadvantage due to educational imbalances. In an Indonesian case, women were hired only as casual labourers and were assigned the tasks of fertilizer and pesticide application, jobs which exposed them to harsh and toxic chemicals (Behrman et al., 2011). Thus the assumption that all job creation is 'good' job creation is actually problematic. In fact, many of the jobs that are created on large land acquisitions pay very poorly and offer few benefits (GRAIN, 2010).

Out-grower schemes can also provide both positive and negative outcomes for participating farmers. If equitably-implemented, out-grower schemes have the potential to increase access to markets and introduce new, more efficient agricultural technologies. However, contracts that bind farmers to particular companies can prevent them from seeking better prices for their goods. As well, crashes in the price of cash crops can leave farmers with loans they cannot repay and crops they cannot sell or eat. Farmers who convert their land to permanent crops such as oil palm or timber monocrops through contracts with an investor, are effectively ceding management control of their land to these companies for what can be several decades, often preventing them from switching the land use to more lucrative or food secure options should the market for timber or palm oil collapse (ABN, 2007; Ramos and Bonilla, 2009).

The export of food from vulnerable countries is an especially controversial issue among critics of LSLAs (Daniel, 2011), and can have a significant impact on livelihoods. A recent study has drawn solid correlations between LSLAs and hunger in the IOW and elsewhere (IFPRI, 2012) (Figure 1). The current study reveals that the majority of LSLAs to lease out land take place in 32 countries ranked 'alarming' or 'serious' in their Global Hunger Index (GHI), most of which are in the IOW. Of these, in seven countries LSLAs account for more than 10 percent of the total agricultural area, and five of these are in the IOW: Cambodia, Ethiopia, Lao PDR, the Philippines, and Indonesia (IFPRI, 2012). Nine other countries in the IOW have GHI cores considered 'serious', another nine have scores that are categorized as 'alarming', and of the three countries in the world with 'extremely alarming' GHI scores, two are in the IOW. Figure 5 shows the correlation between LSLAs and hunger, with IOW countries figuring prominently. Acquisitions made to satisfy local market demands, on the other hand, tend to be less controversial (Smaller and Mann, 2009; Borras and Franco 2010a).

\section{$>>$ Insert figure $5<<$}

Local livelihoods are also impacted as investors seek to halt local community use of forest lands, resulting in resistance and conflict (Hanlon, 2011). This frequently occurs outside of the agreed upon arrangements for investor use of the land. In Mozambique this was such a problem that the Government set up a series of investigations which resulted in the cancellation of some LSLAs (Hanlon, 2011).

Agro-fuel plantations can have particular impact on local livelihoods. In Tanzania, Uganda, Mozambique and elsewhere in the IOW, the conversion of forest land to agro-fuel production has resulted in the displacement of local land holders along with a host of other problems, while at 
the same time offering some employment to local inhabitants as labourers (ABN, 2007; Sulle and Nelson, 2009; WWF, 2009; Hanlon, 2011). ${ }^{7}$ In addition, Brauer and Haywood (2010) cite water conflicts between investors and local populations associated with agro-fuel production, and warn that women's participation in biofuel production can lead to less food production at the household level, which then leads to increases in local food prices. Schoneveld (2010) notes significant land use competition between ago-fuel and local land uses. More generally (Borras and Franco, 2010a) have found that land use conversion to bio-fuels from local uses can compromise the local population's tenure security and community cohesion, and can result in the displacement of traditional land users.

\section{Corruption}

Corruption by local or state government along with investors is commonly suspected in LSLAs but difficult to prove (Emanuelli et al., 2009; Sud, 2009; Palmer, 2010; Tandon, 2010). Of particular concern regarding forests is the speculation surrounding REDD, carbon credits and carbon sequestration opportunities. ${ }^{8}$ Molnar et al. (2011) and RRI (2009) recount that fraudulent actors in Papua New Guinea have deceived local community members into paying $\$ 3$ per person for carbon rights, while the Government reportedly was involved in forcibly signing up landowners to REDD deals to bolster revenue predictions.

A widespread form of corruption exists where investors, enticed by the prospect of being able to pursue money-making opportunities within the area acquired for a specific purpose, can seek to exploit lands for reasons other than what they were acquired for, and outside of the rights granted. This is often done by seeking to expand rights 'on the ground' by convincing local populations that they have been granted such rights, when in reality they do not. This has significant impacts on livelihoods as dislocation and exclusion from local resource use contradicts the agreements that investors, government, and local communities (if included) have come to. For example, concession rights given for mineral, timber, or other extraction activities often do not include the right to exclude local communities from the concession area. However, as enforcement and monitoring capacities remain low in many developing countries, investors of various persuasions can seek to engage in exclusionary practices, so as to pursue a variety of revenue streams that were not part of the initial granting of the concession (e.g. Yasmi et al., 2010; Hanlon, 2011). This can be done by investors or their representatives seeking to take advantage of the educational disparity between local communities and investors. The latter are well aware that local communities have limited knowledge of how statutory property rights work, and so can seek to mislead communities into believing that a concession document, license, or lease is in fact a private property ownership document that allows them to exclude others. In Mozambique, Chikweti Forests of Niassa, a Swedish-based "Global Solidarity Forest Fund" owned by Norwegian and Swedish churches, was investigated by the government

\footnotetext{
${ }^{7}$ In some cases there is of course a relationship between the number of dislocatees and the availability of labourers.

8 Many states have separate laws and policies for forest tenure and land tenure. Contradictions in these laws can serve to facilitate corrupt practices or can hinder an investor's ability to fulfill the promised goals in their leases (Unruh, 2009).
} 
regarding its tree plantation activities (Hanlon, 2011). The Mozambican Prime Minister ordered the investigation and the National Directorate of Lands and Forests found that the company created conflicts of interest by offering family members of local leaders jobs in exchange for permitting the company to operate outside of its legally contracted area (approximately 32,000 hectares had been occupied illegally) (Hanlon, 2011). Additionally, the company promised to plant only in marginal areas, but planted in productive farming areas as well, and cut down native tree species to plant eucalyptus and pine (Hanlon, 2011). ${ }^{9}$

\section{Political unrest and activism}

The 2009 toppling of Madagascar's government has been widely attributed to the government's plan to lease over 1.5 million hectares, or roughly half of the country's arable land, to Indian and South Korean companies through a series of 99 year leases. The subsequent government immediately cancelled the concessions. Apart from this example, the spectre of armed conflict over land rights hangs over many countries being targeted for LSLAs in the IOW. Alden-Wily (2008) notes that at least two-thirds of ongoing armed conflicts globally are driven, in part, by contested rights to land. Both Sudan and Mozambique have been sites of armed conflict and both are some of the top targets for LSLAs by foreign and domestic investors (Deininger and Byerlee, 2011).

Local resistance to LSLAs has resulted in violent conflict with security forces belonging to international companies or with government police and military or paramilitary units acting to support agreements between companies and government (Ramos and Bonilla, 2009; Zander and Durr, 2011). In the case of monocrop tree plantations, local populations have set seedlings and other trees on fire--a form of protest with long-standing historical precedent (Barcellos and Ferreira, 2008; Overbeek, 2010). In Ethiopia over 8.8 million acres in Gambella Region have been leased to state-owned and foreign firms since 2008; with local communities being driven from their land by state security forces, and the communities resisting violently. ${ }^{10}$ Internationally linked resistance to LSLAs has placed pressure on certain international institutions (such as FAO) to develop codes of conduct, guidelines and regulations to try to minimize the negative impacts of LSLAs and make them more 'responsible' (Borras and Franco, 2010a; de Schutter, 2009; Palmer, 2010). The FAO recently released voluntary guidelines for governments concerning LSLAs. Such guidelines are a partial response to broad concerns by different interests over the environmental and social implications of LSLAs.

Social and environmental justice movements have brought media attention to specific LSLAs, stalling some projects and leading to the cancellation of others (e.g., Yasmi et al., 2010; Andrianirina-Ratsialonana et al., 2011; Corbera et al., 2011; Freudenthal et al., 2011). In addition

\footnotetext{
${ }^{9}$ More broadly in Mozambique, after an audit of acquisitions between, 2002 and, 2008, The National Directorate of Lands and Forests cancelled or reduced the land area of 1500 investor contracts due to non-compliance with their acquisition plan (Hanlon, 2011).

10 In one instance local attacks on a Saudi-owned rice plantation in the region resulted in five deaths in April of 2012 (CS, 2012).
} 
internationally networked activist organizations have played a key role in collecting media reports, local accounts and research on the different aspects of LSLAs. ${ }^{11}$ These networks have been a major source of information for the recent summary documents released by the World Bank and other institutions (e.g., Cotula et al., 2011; Deininger and Byerlee, 2011; Friis and Reenberg, 2010). ${ }^{12}$ One of the recent trends of these 'global' organizations has been to connect localized conflict and protests with the broader global activist network in order to demonstrate a larger pattern of appropriation and environmental and social impact and resistance. These global organizations are able to scale-up resistance and lend legitimacy and backing to what would otherwise appear to be isolated cases. However such movements tend to conceal the fact that local communities contain internal social inequities along class, ethnic, racial and gender lines (Borras and Franco, 2010b), and that some sectors of local society can be in favour, assist, or gain from a particular LSLA through jobs, infrastructure improvements and other opportunities (Borras and Franco, 2010b).

\section{Conclusion}

The 'global land grab' has caused significant consternation among host countries and the international development community as powerful government and private interests seek to secure large resource rich and agriculturally endowed tracts of lands outside their own borders. While the academic literature is beginning to describe the process and patterns of LSLAs at the global level, there exists a lack of examination on region- and land type specific drivers, actors, and outcomes. This is particularly problematic in the IOW because this is the region where globally, the process is most robust, constituting most land transactions, the most land area, and most countries involved in transactions. This review seeks to begin to examine some of the primary factors involved in forest-related LSLAs in the IOW, in order to provide preliminary material for further analysis; and to initiate a more critical examination of the role of history, economy, and human - environment interaction in the IOW within the global process and pattern of LSLAs.

\section{Appendix I. Nature of Acquisitions}

Nature of acquisitions in land bordering forests in the IOW

- Agro-fuels

- Food crops

- $\quad$ Livestock

- Non-food agricultural commodities

\footnotetext{
${ }^{11}$ Examples of such activist organizations include, GRAIN, La Via Campesina, Friends of the Earth and the International Land Coalition.

12 Media reports however are less reliable than on-the-ground research that has been triangulated and peer-reviewed, making the efforts of GRAIN and other national and international NGOs vulnerable to appropriation of their information on one hand, and the denial of the validity of their claims on the other. Thus while activist media shaming of companies can force investors to change their plans, pull out of contracts, or re-negotiate, it is difficult to maintain a campaign against a particular LSLA if such NGOs are held to the same standards (scientific, legal, etc.) of evidence production that companies and governments can afford (AFROL News, 2011; Barcellos and Ferreira, 2008).
} 
- Mineral extraction, including petroleum

- Tourism

- Land speculation

- Industry

- Urban development

- Conservation, environmental protection

- Conversion to forest plantations

- Conversion to diverse forests

- Other

Nature of acquisitions in forested land in the IOW

- Acquisition for wood and/or fiber

- Acquisition for carbon sequestration

- Plantation Forests

- Acquisition for non-timber, fiber, plantation forest products (e.g. genetic material)

- Conversion from forest to pasture, or just clearing for timber harvest

- Biodiversity protection, protection of forests

- Conversion from forest to bio-fuels, food production

- Various acquisitions

In addition each LSLA in the bibliographic database is coded according to the following additional characteristics of the acquisitions:

1. Country (where land is affected by land deal)

2. Size of acquisition (ha)

3. Year of Acquisition Agreement (not commencement of operations)

5. Investor (name of firm, organization, individual, etc.)

6. Origin of the investor (Country)

\section{References}

African Biodiversity Network (ABN). (2007), 'Agrofuels in Africa: the impacts on land, food and forest', African Biodiversity Network [online], available at: www.gaiafoundation.org/ documents/AgrofuelsAfrica_sml_Jul2007.pdf accessed 18 November, 2008.

Afrol News. (2011), 'Ethiopian "sacred forests" sold to Indian tea producer', 18 February.

Agarwal, B. (2010), Gender and Green Governance: the Political Economy of Women's Presence within and Beyond Community Forestry. Oxford: Oxford University Press.

Alden Wily, L. (2008), 'Commons and conflict States: why the ownership of the commons matters in making and keeping peace', Washington DC: Rights and Resources Initiative. 
Andrianirina-Ratsialonana, R. et al. (2011), 'After Daewoo? Current status and perspectives of large-scale land acquisitions in Madagascar, Rome: International Land Coalition.

Angelsen, A. (2007), 'Forest cover change in space and time: combining the Von Thunen and forest transition theories', World Bank Policy Research Working Paper 4117. World Bank, Washington, D.C.

Anseeuw, W., Boche, M., Breu, T., Giger, M., Lay, J., Messerli, P., and Nolte, K. (2012), Transnational Land Deals for Agriculture in the Global South: Analytical Report based on the Land Matrix Database. Bern, Switzerland; Montpellier, France; and Hamburg, Germany: Centre for Development and Environment; CIRAD; and German Institute of Global and Area Studies (GIGA).

Barcellos, G.H. and S.B. Ferreira. (2008), Women and Eucalyptus: Stories of Life and Resistance (Impacts of Eucalyptus Monocultures on Indigenous and Quilombola Women in the State of Espírito Santo). Montevideo, Uruguay: WRM.

Brauer, J. and Haywood, R. (2010), Non-state Sovereign Entrepreneurs and Non-territorial Sovereign Organizations. UNU-WIDER, Working Paper No., 2010/09. United Nations University, Tokyo.

Behrman, J., Meinzen-Dick, R. and Quisumbing A. (2011), The Gender Implications of LargeScale Land Deals. IFPRI Discussion Paper 01056, January.

Borras, S. and Franco, J.C. (2010), Towards a Broader View of the Politics of Global Land Grab: Rethinking Land Issues, Reframing Resistance. The Hague, Netherlands: ICAS Working Paper Series No. 001, Published jointly by Initiatives in Critical Agrarian Studies, Land Deal Politics Initiative and Transnational Institute.

Borras, S. and Franco, J.C. (2010), 'From threat to opportunity? problems with the idea of a "code of conduct" for land-grabbing', Yale Human Rights and Development Law Journal, Vol. 13, no. 1, pp. 507-523.

Campbell, G. (2009), The First Global Economy and Human-Environment Interaction. McGill University, Montreal: Proposal submitted to and funded by the Social Sciences and Humanities Research Council of Canada, Major Collaborative Research Initiatives Program.

Casson, A. (2003), Oil Palm, Soybeans and Critical Habitat Loss. Hohlstrasse, Switzerland: World Wildlife Fund Forest Conversion Initiative. 
Cerbu, G., Swallow, B.M. and Thompson, D.Y. (2011), 'Locating REDD: A global survey and analysis of REDD readiness and demonstration activities', Environmental Science and Policy, Vol. 14, pp.168-180.

Corbera, E., Estrada, M., May, P., Navarro, G., Pacheco, P. (2011), 'Rights to land, forests and carbon in REDD+: insights from Mexico, Brazil and Costa Rica', Forests, Vol. 2, pp. 301-342.

Cotula, L. and Mayers, J. (2008), 'Tenure in REDD: start-point or afterthought?' Natural Resource, No. 15.

Cotula, L., Vermeulen, S., Mathieu, P., and Toulmin, C. (2011), 'Agricultural investment and international land deals: evidence from a multi-country study in Africa', Food Security, Vol. 3, (Supplement 1), pp. S99-S113.

Cultural Survival (CS). (2012), 'Ethiopia: violence erupts in Gambella', Cultural Survival, May 10 .

Daley, E. (2011), Gendered Impacts of Commercial Pressures on Land. ILC, CIRAD, Mokoro Ltd.

Daniel, S. (2011), 'Land grabbing and potential implications for world food security', Sustainable Agricultural Development, Vol. 1, pp. 25-42.

Deninger, K., and Byerlee, D. (2011), Rising Interest in Farmland: Can it Yield Equitable and Sustainable Results? Washington DC: The World Bank.

De Schutter, O. (2009), Report from the Special Rapporteur on the Right to Food: Large-Scale Land Acquisitions and Leases: A Set of Minimum Principles and Measures to Address the Human Rights Challenge. United Nations General Assembly.

The Economist. (2011), 'When others are grabbing their land: evidence is piling up against acquisitions of farmland in poor countries', The Economist, 05 May.

Emanuelli, M.S., Jonsén, J. and Monsalve Suárez, S. (eds.) (2009), Red Sugar, Green Deserts: Latin American Report on Monocultures and Violations of the Human Rights to Adequate Food and Housing, to Water, to Land and to Territory. Halmstad, Sweden: FIAN International, FIAN Sweden, HIC-AL, and SAL.

Filippini, A. (2009), 'Tree monocultures and gender', In: Emanuelli, M.S., Jonsen, J. and Suarez, S.M. (eds.) Red Sugar, Green Deserts: Latin American Report on Monocultures and Violations of the Human Rights to Adequate Food and Housing, to Water, to Land and to Territory. Halmstad, Sweden: FIAN International, FIAN Sweden, HIC-AL, and SAL, pp. 123-134. 
Fischer, G., Shah, M., van Velthuizen, H. and Nachtergaele, F. O. (2002), Global Agro-ecological Assessment for Agriculture in the 21st Century, Rome: FAO, and the International Institute for Applied Systems Analysis (IIASA).

Forster, N. and Stanfield, D (1993), Tenure Regimes and Forest Management: Case Studies in Latin America. University of Wisconsin-Madison: Land Tenure Center Paper 147.

Friis, C. and Reenberg. A. (2010), Land Grab in Africa: Emerging Land System Drivers in a Tele-connected World, Copenhagen: GLP Report No. 1. GLP-IPO.

Freudenthal, E., Nnah, S. and Kenrick, K. (2011), REDD and Rights in Cameroon: A Review of the Treatment of Indigenous Peoples and Local Communities in Policies and Projects. Moretonin-Marsh, UK: Forest Peoples Programme.

GRAIN (2010), Unpacking a Chinese company's land grab in Cameroon. GRAIN. Available at http://farmlandgrab.org/16485, accessed 7 December 2012.

GRAIN (2009) Land grabbing and the global food crisis. GRAIN, Barcelona. http:// www.grain.org/go/landgrab

Hallam, D. (2011), 'International investment in developing country agriculture: issues and challenges', Food Security, Vol. 3 (Supplement 1), pp. S91-S98.

Hanlon, J. (ed.) (2011), 'Land moves up the political agenda,' Mozambique Political Process Bulletin, Vol. 48, no. 1, 22 February.

Hughes, C. (2008), 'Cambodia in, 2007: development and dispossession', Asian Survey. Vol. 48, no.1, pp. 69-74.

Instituto Socioambiental and Forest Trends. (2010), Avoided Deforestation (REDD) and Indigenous Peoples: experiences, challenges and opportunities in the Amazon context. São Paulo, Brasil: Instituto Socioambiental.

Karsenty, A. (2010), Large-Scale Acquisition of Rights on Forest Lands in Africa, Washington DC: Rights and Resources Initiative.

Karsenty, A., Jégou, C. and Singeret, B. (2008), Social Policies of Forest Concessionaires in West and Central Africa. Washington, D.C.: Rights and Resources Institute.

Karsenty, A., Drigo, I.G. Piketty, M.G. and Singer, B. (2008), 'Regulating industrial forest concessions in Central Africa and South America', Environmental Science and Policy, Vol.14, pp. 168-180. 
Kugelman, M. and Levenstein, S. (2010) 'Sacrificing the environment for food security', World Politics Review, Jan 20.

Lambin, E.F, and Meyfroidt, E. (2011), 'Global land use change, economic globalization, and the looming land scarcity', Proceedings of the National Academy of Sciences, Vol. 108, no. 9, pp. $3465-3472$.

Lastarria-Cornheil, S. (1997), 'Impact of Privatization on gender and property rights in Africa', World Development, Vol. 25, no. 8, pp. 1317-1333.

McKenna, P. (2009), 'All washed up for Jatropha? : The draught-resistant "dream" biofuel is also a water hog', MIT Technology Review, 09 June.

Minang, P.A., McCall, M. and Bressers, H. (2006), 'Community capacity for implementing clean development mechanism projects within community forests in Cameroon', Environmental Management, Vol. 39, no. 5, pp.615-630.

Mitchell, T. (2002), Rule of Experts: Egypt, Techno-politics, Modernity. Berkeley, CA: University of California Press.

Molnar, A., Barney, K., DeVito, M., Karsenty, A., Elson, D., Benavides, M., Tipula, P., Soria, C., Shearman, P. and France, M. (2011), Large Acquisition of Rights on Forest Lands for Tropical Timber Concessions and Commercial Wood Plantations. Washington DC: Rights and Resources Initiative in cooperation with the International Land Coalition, Rome, Italy.

Monachon, D. and Gonda, N. (2011), Liberalization of ownership versus indigenous territories in the North of Nicaragua: The case of the Chorotegas. Washington DC: International Land Coalition.

Mpoyi, A. (2010), Les Dimensions sociales et environmentales de projets d'acquisition a grande echelle de droits fonciers en republique democratique du congo. Washington, D.C.: World Bank Annual Conference on Land Policy and Administration.

Murphy, R., Woods, J., Black, M., and McManusc, M. (2011), 'Global developments in the competition for land from biofuels', Food Policy, Vol. 36, pp. 552-561.

Nhantumbo, I. and Salomão, A. (2010) Biofuels, Land Access and Rural Livelihoods in Mozambique. London: International Institute for Environment and Development.

Overbeek, W. (2010), The Expansion of Tree Monocultures: Impacts on local peasants communities in the Province of Niassa (Mozambique). WRM series on tree plantations no. 14. Montevideo, Uruguay: World Rainforest Movement (WRM). 
Palmer, R. (2010/2011), Would Cecil Rhodes have signed a Code of Conduct? Reflections on Global Land Grabbing and Land Rights in Africa, Past and Present. Paper presented to the African Studies Association of the UK, Biennial Conference, Oxford, 16-19 September, 2010 (also presented at IDS, Sussex, 2011).

Ping, L. and Nielsen, R. (2010), A Case Study on Large-Scale Forestland Acquisition in China, The Stora Enso Plantation Project in Hepu County, Guangxi Province, Washington, D.C.: The Rights and Resources Initiative in collaboration with the Rural Development Institute.

Rights and Resources Initiative (RRI) (2009), The End of the Hinterland: Forests, Conflict and Climate Change. Washington, D.C : Rights and Resources Initiative.

Rights and Resources Initiative (RRI) (2010-2011), Pushback: Local Power, Global Realignment. Washington, D.C: Rights and Resources Initiative.

Ramos, I. and Bonilla, N. (2009), Women, Communities and Plantations in Ecuador: Testimonials on a Socially and Environmentally Destructive Forestry Model. WRM series on tree plantations no. 12. Montevideo, Uruguay: World Rainforest Movement (WRM).

Schoneveld, G.C. (2010), Potential Land Use Competition from first Generation Biofuel Expansion in Developing Areas. Bogor, Indonesia: Center for International Forestry Research.

Schoneveld, G.C., German, L. Andrade, R. Chin, M. Caroko, W. and Romero-Hernández, O. (2010), The Role of National Governance Systems in Biofuel Development: A Comparative Analysis of Lessons Learned. Bogor, Indonesia: Center for International Forestry Research.

Shanker, C., Dhyani, S.K. (2006), 'Insect pests of Jatropha curcas L. and the potential for their management', Current Science, Vol. 91, pp. 162-163.

Shoresman A (2012) Land Grabbers can Profit from doing the Right Thing. Education Goes Global, http://educationgoesglobal.com/landgrab, visited on 26 August 2013

Smaller, C. and Mann, H. (2009), A Thirst for Distant Lands: Foreign Investment in Agricultural Land and Water. London: International Institute for Sustainable Development.

Sud, N. (2009), 'The Indian state in a liberalizing landscape', Development and Change. 40(4): 645-665.

Sulle, E. and Nelson, F. (2009), Biofuels, Land Access and Rural Livelihoods in Tanzania. London: International Institute of Environment and Development. 
Tandon, N. (2010), 'New agribusiness Investments mean wholesale sell-out for women farmers', Gender \& Development, Vol. 18, no. 3, pp. 03-514.

Unruh, J.D. (2009), 'Land rights in postwar Liberia: the volatile part of the peace process', Land Use Policy, Vol. 26, pp. 425-433.

Unruh, J.D., Cligget, L. and Hay, R. (2005), 'Migrant land rights reception and 'clearing to claim' in Sub-Saharan Africa: A deforestation example from southern Zambia', Natural Resources Forum, Vol. 29, pp. 190-198.

Venter, O. et al. (2009), 'Carbon payments as a safeguard for threatened tropical mammals', Conservation Letters, Vol. 2, pp. 123-129.

von Braun, J. and Meinzen-Dick, R. (2009), "Land Grabbing” by Foreign Investors in Developing Countries: Risks and Opportunities. Washington, D.C.: Policy Brief 13. IFPRI.

Williams, N. (2009), 'Alarm bells over Africa land deals', Current Biology, Vol. 19, no. 23, pp. R1053 - R1054.

World Wildlife Fund (WWF) (2009), Biofuel Industry Study, Tanzania: An Assessment of the Current Situation. Dar es Saalam: World Wide Fund for Nature Tanzania Programme Office (WWF-TPO), March.

Yasmi, Y., Kelley, L and Enters, T. (2010), Conflict over forests and land in Asia. Bangkok, Thailand: The Centre for People and Forests.

Zander, M., and Dürr, J. (2011), Dynamics in Land Tenure, Local Power and the Peasant Economy: The Case of Petén, Guatemala. Paper presented at the International Conference on Global Land Grabbing 6-8 April. Organized by the Land Deals Politics Initiative (LDPI).

Zoomers, A. (2011), 'Introduction: Rushing for Land: Equitable and sustainable development in Africa, Asia and Latin America', Development, Vol. 54, no. 1, pp. 12-20. 